DR. MUHAMMAD SAJID ARSHAD (Orcid ID : 0000-0001-9564-886X)

DR. MUHAMMAD KAMRAN KHAN (Orcid ID : 0000-0001-7989-4219)

DR. HAFIZ ANSAR RASUL SULERIA (Orcid ID : 0000-0002-2450-0830)

5

6

\title{
Evaluation of Gamma Irradiation and Moringa Leaf Powder on Quality Characteristics of Meat Balls under Different Packaging Materials
}

Article type : Original Article
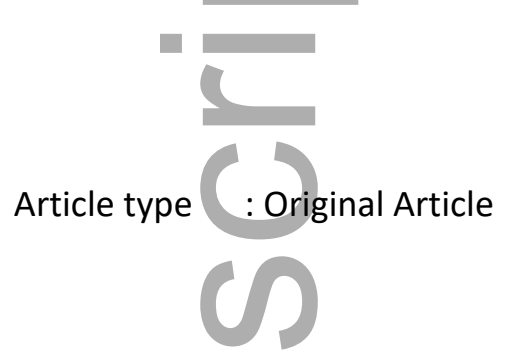

(2)

O

Muhammad Faisal Nisar ${ }^{1}$, Muhammad Sajid Arshad ${ }^{1 *}$, Muhammad Yasin², Muhammad Kamran Khan $^{1}$, Muhammad Afzaal ${ }^{1}$, Saira Sattar ${ }^{1}$ and Hafiz Ansar Rasul Suleria ${ }^{3}$

${ }^{1}$ Department of Food Science, Nutrition and Home Economics, Government College University, Faisalabad-Pakistan

${ }^{2}$ Food Science Division, Nuclear Institute for Food and Agriculture, Pakistan Atomic Energy

Commission Peshawar-Pakistan.

19 3epartment of Agriculture and Food Systems, The University of Melbourne, Melbourne 3010, 20 Australia

21

22

*Corresponding author: E-mail: sajid_ft@yahoo.com, msajidarshad@gcuf.edu.pk

This is the author manuscript accepted for publication and has undergone full peer review but has not been through the copyediting, typesetting, pagination and proofreading process, which may lead to differences between this version and the Version of Record. Please cite this article as doi: $\underline{10.1111 / / F P P .14748}$

This article is protected by copyright. All rights reserved 
Abstract This study was carried out to investigate the effects of irradiation doses $(0,1.5$ and $3 \mathrm{kGy})$ on the 38 physicochemical and microbial qualities of meat balls with or without moringa leaf powder 39 (MLP) and 14 days under refrigerated storage. The results indicated that irradiation and storage 40 caused significant changes on physicochemical attributes of meatballs and the decreasing trend 41 in stability was observed in meatballs stored under aerobic packaging. Highest pH and TVBN 42 were observed in samples treated with $3 \mathrm{kGy}$ at day 14 in aerobic packaging without MLP. The 43 addition of MLP and higher doses of irradiation reduced the total aerobic bacteria and coliforms 44 counts. Different treatments did not affect the sensory quality of chicken samples. Hence, it was 45 concluded that irradiation dose at $1.5 \mathrm{kGy}$ with the addition of MLP and vacuum packaging may 46 enhanced the safety, quality as well as stability of chicken meat during storage intervals. 


\section{Practical application}

The health benefits of meat and its products make them popular among the consumers. Hence, this study indicates the significance of irradiation (at low dose) in preserving the meat for long time without causing immense deteriorative changes in its quality. Moreover, the addition of moringa leaf powder (a natural antioxidant) and type of packaging (vacuum packaging) plays a vital role in maintaining the shelf life and stabilizing the safety of meat without causing major changes in its physicochemical, functional and sensory characteristics.

\section{Introduction}

57 Meat consumption is considered as highly esteem diet in most places around the world due to its high nutritional value. Meat is regarded as a rich source of zinc, essential amino acids, heme iron and bioavailable B vitamins (Pereira \& Vicente, 2013). It is the first-choice source of animal protein for many people all over the world (Ekmekcioglu et al., 2018).

The need for ensuring meat products of high quality, consumer attractiveness and cost effectiveness has made the industrialists, meat processors, distributors and retailers to confirm the availability of these required features (Valdramidis \& Koutsoumanis, 2016). It is not easy for meat-based products to make stable its shelf life in dynamic market due to its high perishability character without employing some appropriate preservation techniques. To enhance the shelf life of meat and its products various traditional preservation approaches have been utilized such as dehydration; heat processing, low temperature preservation, smoking and curing, but these conventional preservation methods have certain restrictions such as average shelf life, expansive and less stability. Moreover, numerous environmental and safety issues are also linked with the application of these methods that may develop serious environmental and health issues. Therefore, for safety enhancement of meat innovative techniques must be used in spite of these traditional methods that do not cause adverse effects on health (Troy et al., 2016). Thus, a wide range of novel processing, packaging and preservation methods has been emerging to increase the shelf stability and quality of meat products. These innovative techniques preserve the meat without disturbing the quality and sensory characteristics of muscle food (Feng et al., 2018). 
Researchers have investigated a novel method that is the use of radiation for the decontamination

77 of meat from different food and meat borne pathogens. It is quite efficient method as it has less residual effect on meat products in comparison to the use of different chemicals for decontamination (FAO, 2016). Radiation was first time applied in food materials at the institute of technology in Massachusetts. It was documented that irradiation can enhance the shelf life and eradicate the microorganisms of food product (Fadhel et al., 2016). Irradiation preserves food products with minimal harm to the nutritional, functional and sensory attributes and has recently become one of the effective techniques for the preservation of food products. Irradiation is considered as preservation technology and gaining importance in muscle food worldwide (Bhat et al., 2016). All types of pathogenic microorganism in meat can be decontaminated by irradiation application but it also has negative effect as it reduces the quality also be applied on different fruits processing for enhancing the safety and shelf life (Panou et al., 2020).

Another major issue in maintaining the quality of meat is lipid oxidation (Feng \& Ahn, 2016). Anti-oxidant addition can resolve the meat oxidation issue. The use of natural preservative is a promising technology to enhance the shelf-life of meat and meat products. Natural preservatives includes plants, herbs, fruits and vegetables powders or extracts have antimicrobial and antioxidant properties. Moringa oleifera is one of the naturally founded antioxidant which is also called as drumstick or horse radish tree is native to Southeast Asia, Arabia, Pakistan, Bangladesh, India, Africa and South America (Falowo et al., 2017). Moringa oleifera L. leaf extracts have been reported in literature as edible and promising sources of natural antioxidants (Bartolome et al., 2013). The leaves have unique concern in the preservation of food as they are highly enriched with proteins, essential amino acids such as cystine, tryptophan, methionine and lysine, minerals (particularly iron) and provitamin A, vitamins B and C (Oyeyinka \& Oyeyinka, 2018) and also because of presence of bioactive substances such as, flavonoids, ascorbic acid, carotenoids and phenolics. It plays a significant role as a natural anti-oxidant and shelf life enhancer (Al-Juhaimi et al., 2016). The combination of gamma irradiation and moringa leaf powder has synergistic effect on the safety of meat products (Nisar et al., 2019).

Application of a novel and advance techniques are useless without applying proper packaging, it has an active role in, safety enhancement, preserving quality and sensory characteristics of the 
product. Plastics are usually used for meat as a packaging material, more specifically, laminates, in which good humidity barrier performance and polymer layers with oxygen-barrier properties like polyamide or polyethylene tetrapthalate. Packaging materials with good oxygen barrier attributes can be employed for low oxygen vacuum packaging. An air-permeable packaging is generally characterized as aerobic packaging, whereas vacuum packaging involves placing a product in a pack possessing low-oxygen permeability.

Considering the facts discussed above, the objective of this study was to determine the antimicrobial effect of irradiation with addition of moringa leaf powder as an antioxidant for safety enhancement of meat and meat products, to improve the shelf life of meat with gamma irradiation and to examine the stability of gamma treated meat under different storage conditions (Aerobic and Vacuum) and time intervals.

\section{Material and methods}

\section{Procurement of raw material}

This research study was conducted at Nuclear Institute for Food and Agriculture, Peshawar (NIFA) and Institute of Home and Food Sciences, Government College University, Faisalabad, Pakistan. The moringa leaf powder (MLP) and chicken meat were collected from the local market. Chicken was grinded and half of the meat was mixed with 2\% MLP. Chicken samples were then placed in polythene bags and were transferred to NIFA for gamma irradiation. All reagents and chemicals used in this study were procured from Sigma Aldrich (Tokyo, Japan).

\section{Irradiation dose}

The chicken meat samples were placed in 12 packets (6 each for aerobic and vacuum packaging). The samples were than subjected to different irradiation doses (0, 1.5 and $3 \mathrm{kGy})$. After treatment the samples were placed in refrigerator storage at $4{ }^{\circ} \mathrm{C}$ up to 14 days. The physicochemical and functional analysis of treated samples was performed at 0,7 and 14 days of interval.

\section{Physicochemical analysis}

\section{pH}

The $\mathrm{pH}$ was determined in a homogenate of the sample with distilled water $(1 \rightarrow 10)$ using a digital pH meter (Model 520A, Orion Research inc., Boston, USA) that was calibrated with 
standard $\mathrm{pH}$ buffers of $4.01,7.00$ and 10.01 at $25{ }^{\circ} \mathrm{C}$. Three replicate measures were taken, and the mean value derived.

\section{Total volatile basic nitrogen value}

The TVBN value was determined as described by Qiao et al., 2017. Meat sample (5 g) was homogenized (Heiddph: 595-08000-00-2, Germany) with $45 \mathrm{~mL}$ of DW for $30 \mathrm{~s} ; 5 \mathrm{~mL}$ of the homogenate was mixed with an equal volume of $10 \%$ trichloroacetic acid (TCA; w/v in distilled water). Thus, obtained TCA extract was used to determine the value of TVBN. One milliliter of TVBN reagent was added into the inner well of the Conway unit, and $1 \mathrm{~mL}$ TCA extract was added into the outer well, followed by the addition of $1 \mathrm{~mL}$ saturated potassium carbonate (K2CO3). The Conway unit was immediately sealed with an airtight ground glass plate, rotated clockwise and counter-clockwise, and incubated at room temperature for $3 \mathrm{~h}$. The TVBN reagent in the inner well was back-titrated with $0.02 \mathrm{~N}$ sulfuric acid (H2SO4) until the blue coloring changed to pink. The TVBN value was calculated using the following equation

" $\mathrm{N} " \mathrm{mg} / \mathrm{mL}$ of extract $=14 \times a \times b$

TVBN value $(\mathrm{mg} / 100 \mathrm{~mL})=100 \times N$

$14=$ molecular weight of nitrogen, $a=$ normality of $\mathrm{H} 2 \mathrm{SO} 4$,

\section{$14=$}

$b=$ volume of $\mathrm{H} 2 \mathrm{SO} 4$, (titration value)

\section{Hunter color}

Hunter colorimeter was used to determine the surface color values of the chicken samples, white calibration plate $(L=89.2, a=0.921$, and $b=0.783)$ is used as standardized measurements. An average of 3 random readings of color values (lightness (L), redness (a), and yellowness (b)) were obtained of each sample surface.

\section{Heme pigment}

The extraction of heme pigments from chicken meat samples were extracted following the protocol of Warriss (1979). Chicken sample (4 g) was homogenized (Heiddph: 595-08000$00-2$, Germany) for $10 \mathrm{~s}$ at $13000 \mathrm{rpm}$ with cold phosphate buffer $(20 \mathrm{~mL}, 40 \mathrm{mM}, \mathrm{pH} 6.8)$. The resultant homogenate was stored for 1 hour at $4^{\circ} \mathrm{C}$. The extract was then subjected to 
165 166

167

168 169

centrifugation for $30 \mathrm{~min}$ at $5000 \mathrm{rpm}$, the mixture was then filtered through Whatman No.1 filter paper. Ultraviolet-visible (UV/VIS) spectrophotometer (U-1800, Japan) was used to measure the absorbance of sample at different wavelength $(525,545,565$, and $572 \mathrm{~nm})$. The method of Krzywicki et al, (1982) was followed to determine the relative concentration of heme pigments, such as myoglobin, oxymyoglobin and metmyoglobin. The relative concentrations (\%) of $\mathrm{Mb}, \mathrm{MbO}_{2}$, and $\mathrm{MMb}$ were calculated using the following equations:

$[\mathrm{Mb}]=\left(0.369 \mathrm{R}_{1}+1.140 \mathrm{R}_{2}-0.941 \mathrm{R}_{3}+0.015\right) \times 100$

$[\mathrm{OxyMb}]=\left(0.882 \mathrm{R}_{1}-1.267 \mathrm{R}_{2}+0.809 \mathrm{R}_{3}-0.361\right) \times 100$

$[\mathrm{MetMb}]=\left(-2.541 \mathrm{R}_{1}+0.777 \mathrm{R}_{2}+0.800 \mathrm{R}_{3}+1.098\right) \times 100$

Where $R_{1}, R_{2}, R_{3}$ are absorbance ratios $A^{572} / A^{525}, A^{565} / A^{525}, A^{545} / A^{525}$, respectively.

\section{Microbial analysis}

The determination of microbes (total aerobic bacteria and coliforms) in chicken samples were done according to the methodology described by Helrich, (1990). Total aerobic bacteria were spread on Plate Count Agar (Merck, Darmstadt, Germany) in petri dishes, which were then incubated at different time and temperature $\left(35^{\circ} \mathrm{C}\right.$ for $24-48$ hour and $25{ }^{\circ} \mathrm{C}$ for $3-5$ days). Enumeration of coliform was performed with solid medium method by using double layer VRBA (Violet Red Bile Glucose Agar, Oxoid) and VRBA (Oxoid) with 4-methlyenebelliferyl-bD-glucuronide (MUG). The plates were then incubated for $18-24$ hour at $35{ }^{\circ} \mathrm{C}$. The total coliforms were counted by the formation of dark red, lactase positive and $0.5-2 \mathrm{~mm}$ diameter colonies surrounded by a reddish zone.

\section{Storage Study}

The irradiated meat samples were kept in storage for 7 and 14 days at $4^{\circ} \mathrm{C}$ to study the changes in its physicochemical and functional analysis throughout the storage interval (Walkling-Ribeiro et al., 2009).

\section{Sensory evaluation}

The sensory evaluation of gamma and moringa leaf powder treated chicken meatballs sample was conducted at storage interval of 0,7 , and 14 by trained panelists using a 9-point hedonic scale where "0" being the lowest and "9" being the highest score (Meilgaard et al., 2007). The 
193 chicken meatballs were analyzed for different quality attributes (appearance, taste, texture, 194 flavor, and overall acceptability).

\section{Statistical analysis}

196 All experiments were conducted in triplicate $(n=3)$ and an ANOVA test using SPSS version 11.5 197 was used to compare the mean values of each treatment. Significant differences between the 198 means of parameters were determined by using the Tukey test $(p<0.05)$ (Steel \& Torrie, 2012).

\section{Results and Discussion}

\section{Physicochemical parameters}

201 The effect of different irradiation doses on the physicochemical parameters of meat samples 202 including $\mathrm{pH}$, hunter color and heme pigment of meat samples incorporated with or without

203

204 205

206

207

208

209

210

211

212

213

214

215

216

217

218

219

220

221 moringa leaf powder were examined. Chemical composition and nutritional quality of meat and meat products are affected by several factors including processing and storage and are also influenced by species. Results for changes in physicochemical parameters $(\mathrm{pH}$, hunter color and heme pigment) of untreated and processed meat samples kept at refrigerator in aerobic and vacuum packaging for a maximum period of 14 days are presented and described.

\section{pH}

$\mathrm{pH}$ is one of the important factor as it is closely related with the stability of the bioactive compounds in meat and meat products (Sánchez-Moreno et al., 2006). The pH value of meat samples with or without moringa leaf powder showed significant decrement $(\mathrm{p} \leq 0.05)$ with the increment of irradiation doses and storage days. The mean values of $\mathrm{pH}$ irradiated with different doses of gamma radiations, stored in aerobic and vacuum packaging are given in (table 1). The $\mathrm{pH}$ value in aerobic and vacuum packaging on 0 day after different treatments ranged from $5.61 \pm 0.01$ to $5.76 \pm 0.01$ respectively, whereas, the $\mathrm{pH}$ values in aerobic packaging during storage ranged from $5.70 \pm 0.01$ to $6.02 \pm 0.01$ and in vacuum packaging ranged from $5.71 \pm 0.02$ to $6.06 \pm 0.01$ respectively. The Higher $\mathrm{pH}$ (more acidic) was found with $1.5 \mathrm{kGy}$ with the addition of $2 \%$ MLF on storage day $0(5.61 \pm 0.01)$ in both aerobic and vacuum packaging; lower $\mathrm{pH}$ $(6.06 \pm 0.01)$ was found with $1.5 \mathrm{kGy}$ without MLF on storage day 14. This result is similar with the findings of Chouliara et al. (2008), who concluded that $\mathrm{pH}$ of irradiated meat samples kept in aerobic and modified atmospheric packaging tends to reduce slightly throughout the storage 
222 period of 25 days. Pelicia et al. (2014) also determined that $\mathrm{pH}$ tends to decrease in meat with the

223 high dose of gamma irradiation kept in both aerobic and vacuum packaging.

224 The increment in $\mathrm{pH}$ level by irradiation processing may be because of the breakdown of lactic 225 acid production and due to hydrolysis of glycogen which accumulates in meat (Kumar et al., 226 2017). The stability of $\mathrm{pH}$ level in irradiated samples with moringa leaf powder is because the 227 radiations and antioxidants inhibit the growth of lactic acid bacteria which causes the rise in $\mathrm{pH}$ 228 in meat samples (Miyagusku et al., 2008).

Total volatile basic nitrogen (TVBN) value

230 The TVBN value of meat samples with or without moringa leaf powder showed significant 231 increment $(\mathrm{p} \leq 0.05)$ with rise of irradiation doses and storage period. The mean TVBN value of meat samples on storage day 0 varied from $2.25 \pm 0.01$ to $4.15 \pm 0.02 \mathrm{mg} / 100 \mathrm{~mL}$ among different applied treatments, whereas the TVBN value during storage in aerobic packaging ranged from $2.43 \pm 0.02$ to $4.51 \pm 0.01 \mathrm{mg} / 100 \mathrm{~mL}$, while in vacuum packaging ranges from $2.37 \pm 0.01$ to $4.42 \pm 0.01 \mathrm{mg} / 100 \mathrm{~mL}$ respectively (Table 1$)$. Higher TVBN value $(4.51 \pm 0.01 \mathrm{mg} / 100 \mathrm{~mL})$ were found in meat samples (without MLF) treated with $3 \mathrm{kGy}$ irradiation dose and stored in aerobic packaging for 14 days. The similar effect of high dose irradiation causing the increment in TBVN value of chicken kababs was examined by Al-Bachir et al. (2010). In another study by Kwon et al. (2011), it was determined that the TVBN level increases in raw and cooked chicken meat when exposed to gamma radiation dose of $0-5 \mathrm{kGy}$.

241

However, it was also demonstrated that the increment in TVBN values were suppressed by 242 irradiation during storage as compared to control and it was also observed that addition of moringa leaf powder also suppressed the production of volatiles in meat samples during storage. The amount of TVBN components also vary in type of packaging, meat samples stored in vacuum packaging showed less value of TVBN throughout the storage as compared to meat samples in aerobic packaging. This result is similar with the findings of Yun et al. (2014), who reported that volatile compounds were enhanced by irradiation process in ready to eat chicken breast, but they tend to increase slowly as compared to un-irradiated meat samples during the storage time period. Furthermore, Li et al. (2017) reported that the volatiles substances found to be increased in high dose irradiated pork samples as compared to low dose irradiated samples during storage. The role of antioxidants in suppressing the volatiles production induced by 
252 irradiation process during storage was demonstrated by Hwang et al. (2015). According to the

253 author the mugwort extracts and ascorbic acids when added into meat samples inhibits the 254 increment of volatile substances during storage.

255 The increment in TVBN level by irradiation processing may be because of the breakdown of nitrogenous compounds present in meat samples (Ahn et al, 2004). The stability of TVBN level in irradiated samples and samples with moringa leaf powder during storage might be due to the

258 fact that irradiation and antioxidants both helps in controlling the production of spoilage bacteria 259 which may causes high amount of TBVN value in meat samples (An et al., 2017). The results are in agreement with the findings of Arshad et al. (2019); Arshad et al. (2020).

Hunter color

Color is one of the most important sensory attribute of any product. The color value of meat samples with or without moringa leaf powder showed significant changes $(p \leq 0.05)$ in all treatments and during storage. The lightness $\mathrm{L}^{*}$ value of meat samples increased till $1.5 \mathrm{kGy}$ dose, whereas it showed decrement with the rise of irradiation dose. On the other hand, the $\mathrm{a}^{*}$ and $b^{*}$ values inereased significantly with the increment of irradiation dose (Table 2). According to the obtained data the higher $\mathrm{L}^{*}, \mathrm{a}^{*}$ and $\mathrm{b}^{*}$ value was observed at $1.5 \mathrm{kGy}$ with $2 \%$ MLF throughout storage in vacuum packaging that ranged from $70.00 \pm 1.00$ to $78.66 \pm 0.57,4.04 \pm 0.05$ to $7.48 \pm 0.01$ and $15.55 \pm 0.09$ to $13.00 \pm 0.100$ respectively, while minimum $L^{*}, a^{*}$ and $b^{*}$ values were observed in control at 0 day.

271 According to our result the storage days do not show any variation in $\mathrm{L}^{*}, \mathrm{a}^{*}$ and $\mathrm{b}^{*}$ color values, 272 but different irradiation treatments significantly affect the color values of meat samples. 273 Moreover, we concluded that meat samples stored in vacuum packaging show minimally 274 changes in color values as compared to meat samples stored in aerobic packaging. The 275 incorporation of natural antioxidant (moringa leaf powder) resulted in the variation in $\mathrm{L}^{*}, \mathrm{a}^{*}$ and $276 b^{*}$ color values of irradiated and non-irradiated samples throughout the storage period in both 277 types of packaging. The similar effect of storage was determined in the study of Li et al. (2017), 278 who examined that $\mathrm{L}^{*}, \mathrm{a}^{*}$ and $\mathrm{b}^{*}$ values of color parameters remain unchanged during storage 279 for 14 days. However, the rise in irradiation doses enhanced the color values. Present results are 280 in agreement with Zhao et al. (2017) on effect of irradiation on quality of vacuum packed 281 chopped beef samples, also agrees with our finding. The authors concluded that color of meat 
282

283

284

285

286

287

288

289

290

291

292

293

294

295

296

297

298

299

300

301

302

303

304

305

306

307

308

309

310

311

samples changes with the increment of irradiation dose level irrespective of storage time and packaging. The change in color as observed in irradiated meat samples incorporated with moringa leaf powder is in favor of previous study by Liz and Getty, (2013), who demonstrated that antioxidants when mixed with meat samples transfers their natural color into the meat thus causing some variation in meat color.

Irradiation degrades the water molecules in meat that generates oxidizing and reducing compounds such as hydroxyl radicals, hydrogen atoms, etc. and lead to the changes in meat color (Thakur and Singh, 1994). The oxidizing compound can convert myoglobin to metmyoglobin and can also lead to lipid oxidation by removing ferric ion from heme, whereas the oxidationreduction potential is lowered by reducing compounds in meat (Min et al., 2010).

\section{Heme Pigment}

The assessment of heme pigment especially myoglobin is used to observe the quality parameters of meat like color, microbial growth, shelf life and rancidity (Chaijan et al., 2007). The heme pigment value of irradiated meat samples with or without moringa leaf powder in aerobic and vacuum packaging showed significant changes $(\mathrm{p} \leq 0.05)$ among all treatments and storage days. The mean values of myoglobin, oxymyoglobin and metmyoglobin are shown in Table 3. The amount of myoglobin varied from $28.98 \pm 0.86$ to $34.08 \pm 0.06 \%$, oxymyoglobin ranged from $8.98 \pm 0.15$ to $11.77 \pm 0.06 \%$ and metmyoglobin ranged from $42.12 \pm 0.31$ to $45.05 \pm 0.04 \%$ respectively, on storage day 0 . The higher value of myoglobin was observed in $3 \mathrm{kGy}$ samples with MLF on day 0 ( $35.65 \pm 0.03 \%$ ), higher value of oxymyoglobin was $20.61 \pm 0.12 \%$, observed

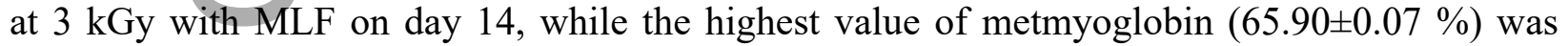
observed on day 14 at $3 \mathrm{kGy}$ without MLF in vacuum packaging.

According to present results, the myoglobin pigment decreased, whereas the oxymyoglobin and metmyoglobin pigments increased with the rise in irradiation dose level and storage days in both aerobic and vacuum packaging. This result correlates with the findings of An et al. (2017) who reported that heme pigments of irradiated smoked duck meat increased during storage except myoglobin which tends to decrease with the increase in storage days. Reddy et al. (2015), also reported that myoglobin pigment decreased during storage, whereas, oxymyoglobin and metmyoglobin increased as the storage day increases in irradiated samples of mutton kheema. In our study, we also found that the heme pigments level in the meat samples incorporated with 
312 moringa leaf powder though exhibited the same trend as meat samples without the antioxidant,

313 but the level of heme pigments is greater in those samples as compared to ones without 314 antioxidants. Cunha et al. (2018), also examined that addition of antioxidants in meat samples 315 slightly inhibits the degradation of myoglobin during storage, thus provided better contents of 316 heme pigments in meat samples.

317 The irradiation process through many different mechanisms causes the catabolism of myoglobin 318 pigment into oxymyoglobin and metmyoglobin pigments thus resulting in decrement of 319 myoglobin level and increment in other two pigment compounds. Myoglobin possess prooxidant 320 capacities by many ways as it could act as a free radical by decomposing hydroperoxide. free 321 radicals helps in lipid oxidation and produces hydroxyl radicals from water that converts myoglobin into metmyoglobin due to ionizing radiation (Aliakbarlu et al., 2015).

\section{Microbial analysis}

324 The effect of different irradiation doses on the microbes of irradiated and non-irradiated meat 325 samples with or without moringa leaf powder were examined before and after storage under 326 vacuum and aerobic packaging. Total aerobic bacteria and coliform values of irradiated meat 327 samples with or without moringa leaf powder showed significant changes $(\mathrm{p} \leq 0.05)$ in all 328 treatment and storage time interval (Table 4). The results of total bacterial count in meat samples 329 after being exposed to irradiation processing, demonstrate that irradiation have the great potential in minimizing and eliminating the microbes from the meat and meat products. The highest value of TAB was found in control $(9.81 \pm 0.04 \log \mathrm{CFU} / \mathrm{g})$ on day 14 in aerobic packaging, whereas

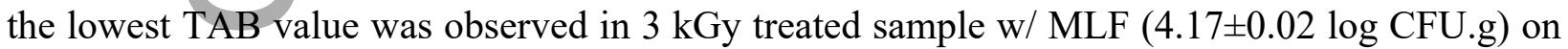
day 0. Coliforms were only discovered in control samples with or without MLF, whereas, they were absent in all irradiated meat samples. The similar effect of gamma irradiation eradicating the microbes from fried chicken dices was observed by Chen et al. (2016). Kanatt et al. (2010), also examined the effect of irradiation in controlling the growth of microorganism in different meat products. The gamma radiation eradicating the no of coliforms in smoked duck meat samples was also reported by An et al. (2017). Moreover, according to our result, the incorporation of Moringa leaf powder in meat samples act as a resistant against microbial growth, therefore, the no of bacterial count become more less in antioxidant meat samples after irradiation as compare to non-antioxidant irradiated meat samples. This examinations corelates 
with the observation of Cunha et al. (2018), who demonstrate that antioxidants play a vital role in preserving the different meat products.

Though irradiation reduced the amount of TAB but during storage their number tends to increase slightly. On the other hand, irradiation eradicates the coliforms from the meat samples which do not appear in storage days as well. These findings agree with the observations of Fallah et al. (2010) who examined that gamma radiation inactivates pathogenic bacteria from chicken meat samples, moreover very less amount of bacteria were found in irradiated samples when kept in storage for 25 days. In another study, Mantilla et al. (2011) reported that the shelf life of chicken breast fillets improves with the irradiation treatment and when kept in storage under vacuum packaging as compared to unirradiated samples in aerobic packaging. Henriques et al. (2013) and Arzina et al. (2012) also reported that irradiation dosage of $1.5-2.5 \mathrm{kGy}$ is enough to eradicate the pathogenic bacteria in refrigerated stored meat samples. The growth of microorganism is controlled by irradiation process as it kills them with its high doses of radiation (Montiel et al., 2013).

\section{Sensory evaluation}

Sensory assessment of a product correlates with consumer approach, believes and awareness. Product development requires an efficient hedonic evaluation for documentation and interpretation of sensory results perceived by the trained panelists. The mean sensory score of appearance, flavor, texture, taste and overall acceptability of formulated chicken meatballs in aerobic and vacuum packaging are shown in Tables 5 and 6, respectively. According to present results, different treatments did not affect the sensory result, but it showed variation with storage days and type of packaging. the highest value of appearance (8.25 \pm 0.70$)$, flavor (7.5 \pm 1.35$)$, texture (7.1 \pm 0.77$)$, taste $(7.3 \pm 1.03)$, overall acceptability $(7.5 \pm 0.81)$ was awarded to control $(0$ kGy) on day 0 in both aerobic and vacuum packaged meatballs samples. Whereas the lowest value of appearance $(6.1 \pm 1.43$ in aerobic packaging), flavor (6.1 \pm 0.90 in vacuum packaging), texture (5.7 \pm 1.20 in aerobic packaging), taste $(6.0 \pm 0.90$ in vacuum packaging) and overall acceptability (6.2 \pm 0.90 in vacuum packaging) is also at $0 \mathrm{kGy}$ but on storage day 14 .

The sensory attributes showed decrement in their value throughout the storage time. These findings are in accordance with Fallah et al. (2010) who concluded that appearance score of both irradiated and non-irradiated samples were good at day 1, but after storage day 15 the non- 
372 irradiated barbecued chicken exhibit less sensory score as compared to irradiated one. Al-Bachir

373 et al. (2010) also reported that the flavor of prepared chicken kababs was well accepted by the

374 panelist without irradiation treatment on day 1, all irradiated chicken kababs were also had good

375 sensory score on day 1 and throughout the storage period, but non-irradiated samples start losing

376 their acceptability of flavor as the storage days increases. Regarding texture, Benerjee et al.

377 (2016), reported that the hardness, chewiness and gumminess in mutton patties were lower in

378 control on day 0 , as compared to irradiated mutton patties. Furthermore, Gertzou et al. (2017)

379 reported that sensory attributes are better with combination of vacuum packaging and ozonation.

380 In another study by Kanatt et al. (2005), it was observed that un-irradiated meat products

381 exhibited good taste on day 1 but when kept in storage their taste become less accepted due to

382 bacteria which altered the taste as compared to irradiated meat products which inhibited the

383 growth of pathogenic bacteria. Irradiation facilitated the lipid oxidation which cause changes in 384 sensory attributes and made the product less acceptable, but overall acceptability was in the 385 range of acceptance.

386 Conclusion

387 This study indicated that irradiation preserves food products with minimal harm to the 388 nutritional, functional and sensory attributes at lower doses. Phytochemicals originating from 389 moringa leaf powder play an important role in stabilizing and protecting the fat, amino acid and 390 other physicochemical and functional components in meat and meat products. The type of 391 packaging helped in extending the shelf life of meat and meat products. The irradiation doses minimize the total aerobic bacteria and eliminates the coliform from the meat samples during 393 storage. Different treatments did not affect the sensory quality of chicken meatballs, but the 394 variation was observed with the storage period.

\section{Authors' contributions}

396 The contribution of the each author for this manuscript was as follows, MSA and MY designed 397 the experimental plan and MFS conducted the analysis and drafted the manuscript. MKK and 398 MA helped in execution of the project. MARS helped in revising the manuscript and SS helped 399 in data analysis. It is also confirmed that all the authors read and approved the final manuscript.

\section{References}


Ahn, D. U., Kim, I. S., \& Lee, E. J. (2013). Irradiation and additive combinations on the pathogen reduction and quality of poultry meat. Poultry science, 92(2), 534-545.

Ahn, D. U., \& Lee, E. J. (2004). Mechanisms and prevention of off-odor production and color changes in irradiated meat. Irradiation of food and packaging: Recent developments, 875 , $43-76$.

Ahn, D. U., Lee, E. J., \& Mendonca, A. (2017). Meat decontamination by irradiation Advanced Technologies for Meat Processing, Second Edition (pp. 197-226): CRC Press.

Al-Bachir, M., Farah, S., \& Othman, Y. (2010). Influence of gamma irradiation and storage on the microbial load, chemical and sensory quality of chicken kabab. Radiation Physics and Chemistry, 79(8), 900-905

Al-Juhaimi, F., Ghafoor, K., Hawashin, M. D., Alsawmahi, O. N., \& Babiker, E. E. (2016). Effects of different levels of Moringa (Moringa oleifera) seed flour on quality attributes of beef burgers. CyTA-Journal of Food, 14(1), 1-9

Aliakbarlu, J., Mohammadi, S., \& Khalili, S. (2014). A Study on Antioxidant Potency and Antibacterial Activity of Water Extracts of Some Spices Widely Consumed in I ranian Diet. Journal of food biochemistry, 38(2), 159-166

An, K. A., Arshad, M. S., Jo, Y., Chung, N., \& Kwon, J. H. (2017). E-Beam Irradiation for Improving the Microbiological Quality of Smoked Duck Meat with Minimum Effects on Physicochemical Properties During Storage. Journal of food science, 82(4), 865-872.

Arshad, M. S., Kwon, J. H., Ahmad, R. S., Ameer, K., Ahmad, S., \& Jo, Y. (2020). Influence of E-beam irradiation on microbiological and physicochemical properties and fatty acid profile of frozen duck meat. Food Science \& Nutrition, 8(2), 1020-1029.

Arshad, M. S., Amjad, Z., Yasin, M., Saeed, F., Imran, A., Sohaib, M., ... \& Hussain, S. (2019). Quality and stability evaluation of chicken meat treated with gamma irradiation and turmeric powder. International Journal of Food Properties, 22(1), 154-172. 
443 444 445 446

447 448

449

450

451

452

453 454

455

456

457

458

459 460

Arzina, H., Hasan, M. Z., Al-Mahin, A., \& Or-Rashid, H. (2012). Effect of gamma radiation and low temperature on pathogenic Staphylococcus aureus isolated from pizza. Am. J. Food Technol, 7, 204-213

Bartolome, A. P., Villaseñor, I. M., \& Yang, W.-C. (2013). Bidens pilosa L.(Asteraceae): botanical properties, traditional uses, phytochemistry, and pharmacology. Evidence-based complementary and alternative medicine, 2013

Bhat, N. A., Wani, I. A., Hamdani, A. M., Gani, A., \& Masoodi, F. (2016). Physicochemical properties of whole wheat flour as affected by gamma irradiation. LWT-Food Science and Technology, 71, 175-183

Banerjee, R., Jayathilakan, K., Chauhan, O. P., Naveena, B. M., Devatkal, S., \& Kulkarni, V. V. (2017). Vacuum Packaged Mutton Patties: Comparative Effects of High Pressure Processing and Irradiation. Journal of Food Processing and Preservation, 41(1), e12880.

Chaijan M, Benjakul S, Visessanguan W, Lee S, Faustman C. 2007. The effect of freezing and aldehydes on the interaction between fish myoglobin and myofibrillar proteins. J Agric Food Chem 55(11):4562-8.

Chen, Q., Cao, M., Chen, H., Gao, P., Fu, Y., Liu, M., ... \& Huang, M. (2016). Effects of gamma irradiation on microbial safety and quality of stir fry chicken dices with hot chili during Storage. Radiation Physics and Chemistry, 127, 122-126.

Chouliara, E., Badeka, A., Savvaidis, I., \& Kontominas, M. G. (2008). Combined effect of irradiation and modified atmosphere packaging on shelf-life extension of chicken breast meat: microbiological, chemical and sensory changes. European Food Research and Technology, 226(4), 877-888.

Conway, E. (1947). Microdiffusion analysis and volumetric error. Crosby Lockwood And Son Ltd.; London 
Cunha, L. C., Monteiro, M. L. G., Lorenzo, J. M., Munekata, P. E., Muchenje, V., de Carvalho, F. A. L., \& Conte-Junior, C. A. (2018). Natural antioxidants in processing and storage stability of sheep and goat meat products. Food Research International, 111, 379-390.

Ekmekcioglu, C., Wallner, P., Kundi, M., Weisz, U., Haas, W., \& Hutter, H.-P. (2018). Red meat, diseases, and healthy alternatives: A critical review. Critical reviews in food science and nutrition, 58(2), 247-261.

Fadhel, Y. B., Leroy, V., Dussault, D., St-Yves, F., Lauzon, M., Salmieri, S., . . L Lacroix, M. (2016). Combined effects of marinating and $\gamma$-irradiation in ensuring safety, protection of nutritional value and increase in shelf-life of ready-to-cook meat for immunocompromised patients. Meat Science, 118, 43-51.

Fallah, A. A., Saei-Dehkordi, S. S., Rahnama, M., Tahmasby, H., \& Mahzounieh, M. (2012). Prevalence and antimicrobial resistance patterns of Listeria species isolated from poultry products marketed in Iran. Food Control, 28(2), 327-332.

Falowo, A., Muchenje, V., Hugo, A., Aiyegoro, O., \& Fayemi, P. (2017). Antioxidant activities of Moringa oleifera L. and Bidens pilosa L. leaf extracts and their effects on oxidative stability of ground raw beef during refrigeration storage. CyTA-Journal of Food, 15(2), 249-256.

FAO, I. (2016). WFP (2015), The State of Food Insecurity in the World 2015. Meeting the 2015 international hunger targets: taking stock of uneven progress. Food and Agriculture Organization Publications, Rome.

Feng, X., \& Ahn, D. U. (2016). Volatile profile, lipid oxidation and protein oxidation of irradiated ready-to-eat cured turkey meat products. Radiation Physics and Chemistry, 127, 27-33. 
Feng, X., Jo, C., Nam, K. C., \& Ahn, D. U. (2018). Effect of irradiation on the parameters that influence quality characteristics of raw beef round eye. Innovative Food Science \& Emerging Technologies, 45, 115-121.

Gertzou, I. N., Karabagias, I. K., Drosos, P. E., \& Riganakos, K. A. (2017). Effect of combination of ozonation and vacuum packaging on shelf life extension of fresh chicken legs during storage under refrigeration. Journal of Food Engineering, 213, 18-26.

Helrich, K. (1990). Official methods of analysis of the AOAC International: Arlington, US: Association of Official Analytical Chemists, 1990.

Henriques-Normark, B., \& Tuomanen, E. I. (2013). The pneumococcus: epidemiology, microbiology, and pathogenesis. Cold Spring Harbor perspectives in medicine, 3(7), a010215.

Hwang, K. E., Kim, H. W., Song, D. H., Kim, Y. J., Ham, Y. K., Lee, J. W., ... \& Kim, C. J. (2015). Effects of antioxidant combinations on shelf stability of irradiated chicken sausage during storage. Radiation Physics and Chemistry, 106, 315-319.

Kanatt, S. R., Chander, R., Radhakrishna, P., \& Sharma, A. (2005). Potato peel extract a natural antioxidant for retarding lipid peroxidation in radiation processed lamb meat. Journal of Agricultural and Food Chemistry, 53(5), 1499-1504.

Kanatt, S. R., Rao, M. S., Chawla, S. P., \& Sharma, A. (2010). Shelf-life extension of convenience meat products sold in Indian supermarkets by radiation processing. Radiation Physics and Chemistry, 79(12), 1259-1263.

Krzywicki, K. (1982). The determination of haem pigments in meat. Meat Science, 7(1), 29-36.

Kumar, S., Khadka, M., Mishra, R., Kohli, D., \& Upadhaya, S. (2017). Effects of conventional and microwave heating pasteurization on physiochemical properties of pomelo (Citrus maxima) juice. Journal of Food Processing and Technology, 8(7). 
521 Kwon, J. H., Akram, K., Nam, K. C., Lee, E. J., \& Ahn, D. U. (2011). Evaluation of radiation-

522

523

524

525

526

527

528

529

530

531

532

533

534

535

536

537

538

539

540

541

542

543

544

545

546

547

548

549

550

551 induced compounds in irradiated raw or cooked chicken meat during storage. Poultry science, $90(11), 2578-2583$

Li, C., He, L., Jin, G., Ma, S., Wu, W., \& Gai, L. (2017). Effect of different irradiation dose treatment on the lipid oxidation, instrumental color and volatiles of fresh pork and their changes during storage. Meat science, 128, 68-76

Liz, K. L. K. (2013). Getty KJK Natural antioxidants in meat and poultry products: A review. Meat Sci, 94, 220-227.

Mantilla, S. P. S., Santos, É. B., Vital, H. D. C., Mano, S. B., Freitas, M. Q. D., \& Franco, R. M. (2011). Microbiology, sensory evaluation and shelf life of irradiated chicken breast fillets stored in air or vacuum. Brazilian Archives of Biology and Technology, 54(3), 569-576.

Meilgaard, M., Civille, G., \& Carr, B. (2007). Overall difference tests: does a sensory difference exist between samples. Sensory evaluation techniques, 4, 63-104.

Min, S. H., Yang, J. H., Kim, J. Y., \& Kwon, Y. U. (2010). Development of white antibacterial pigment based on silver chloride nanoparticles and mesoporous silica and its polymer composite. Microporous and Mesoporous Materials, 128(1-3), 1925.

Miyagusku, L. (2008). Influencia da radiação ionizante (60Co) na manutenção da qualidade fisico-quimica, microbiologica e sensorial de cortes de coxa e file de peito de frango acondicionado em deiferentes sistemas de embalagens

Montiel R, Cabeza MC, Bravo D, Gaya P, Cambero I, Ord'õnez JA, Nũ̃nez M, Medina M. 2013. A comparison between e-beam irradiation and high-pressure treatment for cold smoked salmon sanitation: shelf-life, colour, texture and sensory characteristics. Food Bioprocess Tech 6(11):3177-85 
Nisar, M. F., Arshad, M. S., Yasin, M., Arshad, M. U., \& Nadeem, M. T. (2019). Influence of irradiation and moringa leaf powder on the amino acid and fatty acid profiles of chicken meat stored under various packaging materials. Journal of Food Processing and Preservation, 43(9), e14166.

Oyeyinka, A. T., \& Oyeyinka, S. A. (2018). Moringa oleifera as a food fortificant: Recent trends and prospects. Journal of the Saudi Society of Agricultural Sciences, 17(2), 127-136.

Panou, A. A., Karabagias, I. K., \& Riganakos, K. A. (2020). Effect of Gamma-Irradiation on Sensory Characteristics, Physicochemical Parameters, and Shelf Life of Strawberries Stored under Refrigeration. International Journal of Fruit Science, 20(2), 191-206.

Pearson, R. G. (1968). Hard and soft acids and bases, HSAB, part II: Underlying theories. Journal of Chemical Education, 45(10), 643

Pelicia, K., Garcia, E. A., Molino, A. B., Santos, G. C., Vieira Filho, J. A., Santos, T. A., \& Berto, D. A. (2015). Chicken Meat Submitted to Gamma Radiation and Packed with or without Oxygen. Revista Brasileira de Ciência Avícola, 17(2), 255-261.

Pereira, P. M. d. C. C., \& Vicente, A. F. d. R. B. (2013). Meat nutritional composition and nutritive $\quad$ role in the human diet. Meat Science, 93(3), 586-592.

Reddy KJ, Jayathilakan K, Pandey MC. 2015. Effect of ionizing radiation on the protein and lipid quality characteristics of mutton kheema treated with rice bran oil and sunflower oil. Rad Phys Chem 117:217-24.

Sánchez-Moreno, C., Plaza, L., de Ancos, B., \& Cano, M. P. (2003). Quantitative bioactive compounds assessment and their relative contribution to the antioxidant capacity of commercial orange juices. Journal of the Science of Food and Agriculture, 83(5), 430439.

Steel, R., \& Torrie, J. (2012). Principles and procedures of statistics: a Biometrical approach MCGraw-Hill Book Company Toronto. Redvet, 13(6), 481. 
581 Thakur, B. R., \& Singh, R. K. (1994). Food irradiation-chemistry and applications. Food Reviews International, 10(4), 437-473

583

584 585

586

587

588

589

590

591

592

593

594

595

596

597

598

599

600

601

Troy, D. J., Ojha, K. S., Kerry, J. P., \& Tiwari, B. K. (2016). Sustainable and consumer-friendly emerging technologies for application within the meat industry: An overview. Meat Science, 120, 2-9.

Valdramidis, V. P., \& Koutsoumanis, K. P. (2016). Challenges and perspectives of advanced technologies in processing, distribution and storage for improving food safety. Current Opinion in Food Science, 12, 63-69.

Walkling-Ribeiro, M., Noci, F., Cronin, D., Lyng, J., \& Morgan, D. (2009). Shelf life and sensory evaluation of orange juice after exposure to thermosonication and pulsed electric fields. Food and Bioproducts Processing, 87(2), 102-107.

Warriss, P. (1979). Adrenal ascorbic acid depletion as an index of preslaughter stress in pigs.

Meat Science, 3(4), 281-285

Yun, H., Lee, K. H., Lee, H. J., Lee, J. W., Ahn, D. U., \& Jo, C. (2012). Effect of high-dose irradiation on quality characteristics of ready-to-eat chicken breast. Radiation Physics and Chemistry, 81(8), 1107-1110.

Zhao, L., Zhang, Y., Guo, S., Xiong, W., Xia, H., Liu, W., \& Venkitasamy, C. (2017). Effect of Irradiation on Quality of Vacuum-Packed Spicy Beef Chops. Journal of Food Qality, 2017. 


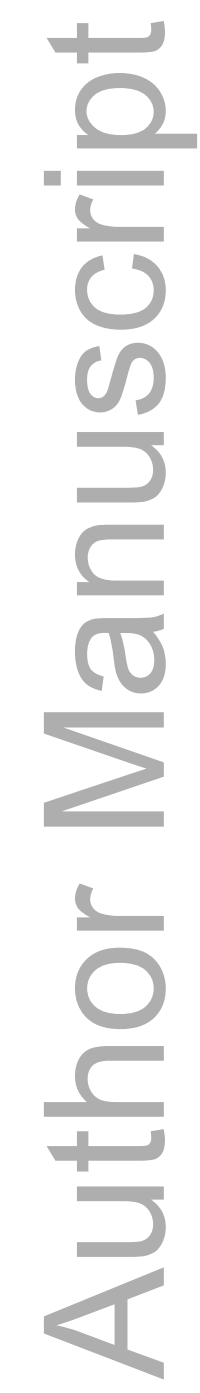

This article is protected by copyright. All rights reserved 
Table 1. pH and TVBN in aerobic and vacuum packaged meat samples during storage

\begin{tabular}{|c|c|c|c|c|c|}
\hline & & \multicolumn{2}{|c|}{ pH } & \multicolumn{2}{|c|}{ TVBN ( mg/100mL) } \\
\hline & & Aerobic & Vacuum & Aerobic & Vacuum \\
\hline & 0 & $5.76 \pm 0.01^{\mathrm{f}}$ & $5.76 \pm 0.01^{\mathrm{g}}$ & $2.76 \pm 0.02^{\mathrm{a}}$ & $2.76 \pm 0.02^{\mathrm{a}}$ \\
\hline & 7 & $5.88 \pm 0.01^{\mathrm{cd}}$ & $5.82 \pm 0.01^{\mathrm{e}}$ & $3.20 \pm 0.01^{\mathrm{b}}$ & $3.01 \pm 0.02^{\mathrm{b}}$ \\
\hline & 14 & $5.97 \pm 0.01^{\mathrm{b}}$ & $5.93 \pm 0.01^{\mathrm{bc}}$ & $3.54 \pm 0.02^{\mathrm{c}}$ & $3.27 \pm 0.02^{\mathrm{b}}$ \\
\hline & 0 & $5.70 \pm 0.01^{\mathrm{g}}$ & $5.70 \pm 0.01^{\mathrm{ef}}$ & $3.70 \pm 0.02^{c}$ & $3.70 \pm 0.02^{c}$ \\
\hline $1.5 \mathrm{kGy}$ & 7 & $5.82 \pm 0.01^{\mathrm{e}}$ & $5.97 \pm 0.01^{\mathrm{b}}$ & $3.89 \pm 0.02^{\mathrm{d}}$ & $3.82 \pm 0.02^{\mathrm{d}}$ \\
\hline & 14 & $5.95 \pm 0.01^{b}$ & $6.06 \pm 0.01^{\mathrm{a}}$ & $3.97 \pm 0.01^{\mathrm{e}}$ & $3.78 \pm 0.01^{\mathrm{c}}$ \\
\hline & 0 & $5.77 \pm 0.01^{\mathrm{f}}$ & $5.77 \pm 0.01^{\mathrm{hi}}$ & $4.15 \pm 0.02^{\mathrm{e}}$ & $4.15 \pm 0.02^{\mathrm{b}}$ \\
\hline & 7 & $5.90 \pm 0.01^{\mathrm{c}}$ & $5.81 \pm 0.04^{\mathrm{ef}}$ & $4.44 \pm 0.01^{\mathrm{f}}$ & $4.36 \pm 0.01^{\mathrm{e}}$ \\
\hline & 14 & $6.02 \pm 0.01^{\mathrm{a}}$ & $5.91 \pm 0.01^{\mathrm{cd}}$ & $4.51 \pm 0.01^{\mathrm{e}}$ & $4.42 \pm 0.01^{\mathrm{ef}}$ \\
\hline & 0 & $5.67 \pm 0.01^{\mathrm{gh}}$ & $5.67 \pm 0.01^{\mathrm{i}}$ & $2.25 \pm 0.01^{\mathrm{a}}$ & $2.25 \pm 0.01^{\mathrm{a}}$ \\
\hline$\% \mathrm{MLF}$ & 7 & $5.74 \pm 0.01^{\mathrm{f}}$ & $5.76 \pm 0.03^{\mathrm{fg}}$ & $2.43 \pm 0.02^{\mathrm{a}}$ & $2.37 \pm 0.01^{\mathrm{a}}$ \\
\hline & 14 & $5.82 \pm 0.01^{\mathrm{e}}$ & $5.86 \pm 0.01^{\mathrm{de}}$ & $2.51 \pm 0.02^{\mathrm{a}}$ & $2.45 \pm 0.01^{\mathrm{a}}$ \\
\hline & 0 & $5.61 \pm 0.01^{\mathrm{i}}$ & $5.61 \pm 0.01^{\mathrm{gh}}$ & $3.36 \pm 0.01^{\mathrm{c}}$ & $3.36 \pm 0.01^{\mathrm{c}}$ \\
\hline $1.5 \mathrm{kGy}+2 \% \mathrm{MLF}$ & 7 & $5.70 \pm 0.01^{\mathrm{g}}$ & $5.89 \pm 0.01^{\mathrm{cd}}$ & $3.58 \pm 0.02^{\mathrm{bc}}$ & $3.50 \pm 0.02^{\mathrm{bd}}$ \\
\hline & 14 & $5.86 \pm 0.01^{\mathrm{d}}$ & $5.99 \pm 0.01^{b}$ & $3.71 \pm 0.01^{\mathrm{c}}$ & $3.59 \pm 0.02^{c}$ \\
\hline & 0 & $5.67 \pm 0.01^{\mathrm{h}}$ & $5.67 \pm 0.01^{\mathrm{j}}$ & $3.67 \pm 0.01^{\mathrm{c}}$ & $3.67 \pm 0.01^{\mathrm{c}}$ \\
\hline
\end{tabular}

This article is protected by copyright. All rights reserved 


\begin{tabular}{cccccc}
$3 \mathrm{kGy}+2 \%$ MLF & 7 & $5.77 \pm 0.01^{\mathrm{f}}$ & $5.71 \pm 0.02^{\mathrm{gh}}$ & $3.78 \pm 0.01^{\mathrm{d}}$ & $3.70 \pm 0.01^{\mathrm{d}}$ \\
& 14 & $5.88 \pm 0.01^{\mathrm{cd}}$ & $5.86 \pm 0.02^{\mathrm{de}}$ & $3.89 \pm 0.01^{\mathrm{d}}$ & $3.77 \pm 0.01^{\mathrm{d}}$ \\
\hline
\end{tabular}

Results are means of triplicates $( \pm \mathrm{SD})$. Values with different letters in columns are significantly different (Tukey’s test, $\mathrm{p} \leq 0.05)$. MLF; Moringa

Leaf Powder

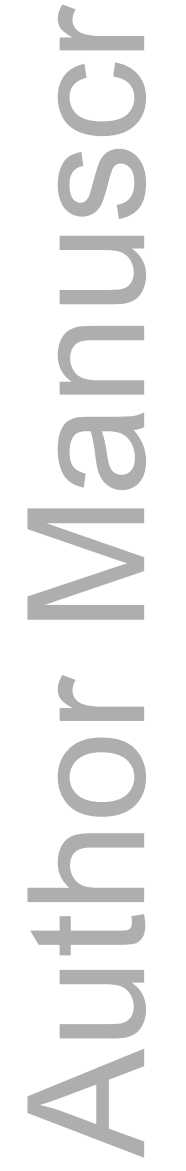

This article is protected by copyright. All rights reserved 


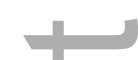

Table 2. Hunter color in aerobic and vacuum packaged meat samples during storage

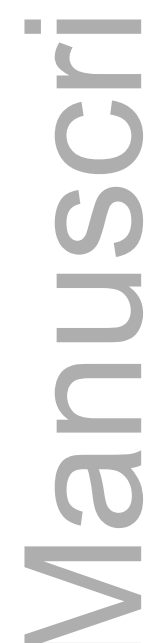

Results are means of triplicates $( \pm$ SD). Values with different letters in columns are significantly different (Tukey’s test, $p \leq 0.05)$. MLF; Moringa Leaf Powder

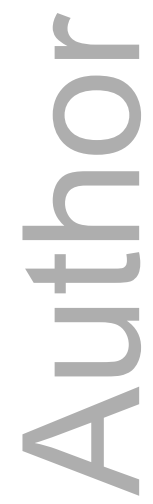

This article is protected by copyright. All rights reserved 


\begin{tabular}{|c|c|c|c|c|c|c|c|}
\hline \multirow{2}{*}{$\begin{array}{c}\text { Treatments } \\
\end{array}$} & \multirow[t]{2}{*}{ Storage Days } & \multicolumn{3}{|c|}{ Aerobic } & \multicolumn{3}{|c|}{ Vacuum } \\
\hline & & $\mathbf{L}^{*}$ & $\mathbf{a}^{*}$ & $\mathbf{b}^{*}$ & $\mathbf{L}^{*}$ & $\mathbf{a}^{*}$ & $\mathbf{b}^{*}$ \\
\hline \multirow[t]{3}{*}{ 0kGy } & 0 & $54.00 \pm 1.00^{\mathrm{def}}$ & $4.04 \pm 0.06^{\mathrm{h}}$ & $13.00 \pm 0.100^{\mathrm{i}}$ & $54.00 \pm 1.00^{\mathrm{ef}}$ & $4.04 \pm 0.05^{\mathrm{f}}$ & $13.00 \pm 0.100^{\mathrm{g}}$ \\
\hline & 7 & $53.00 \pm 1.00^{\mathrm{ef}}$ & $4.05 \pm 0.01^{\mathrm{h}}$ & $12.96 \pm 0.01^{\mathrm{i}}$ & $58.00 \pm 1.00^{\mathrm{f}}$ & $4.24 \pm 0.01^{\mathrm{f}}$ & $13.38 \mathrm{~V} 0.03^{\mathrm{g}}$ \\
\hline & 14 & $51.33 \pm 1.52^{\mathrm{f}}$ & $4.08 \pm 0.01^{\mathrm{h}}$ & $12.85 \pm 0.05^{\mathrm{i}}$ & $56.66 \pm 0.57^{\mathrm{f}}$ & $4.29 \pm 0.01^{\mathrm{f}}$ & $13.77 \pm 0.02^{\mathrm{fg}}$ \\
\hline \multirow[t]{3}{*}{$1.5 \mathrm{kGy}$} & 0 & $61.00 \pm 1.00^{\mathrm{b}}$ & $5.57 \pm 0.04^{\mathrm{f}}$ & $14.23 \pm 0.15^{\mathrm{de}}$ & $61.00 \pm 1.00^{\mathrm{b}}$ & $5.57 \pm 0.04^{\mathrm{d}}$ & $14.23 \pm 0.15^{\mathrm{c}}$ \\
\hline & 7 & $62.66 \pm 0.57^{b}$ & $5.56 \pm 0.01^{\mathrm{f}}$ & $14.18 \pm 0.03^{\mathrm{def}}$ & $71.33 \pm 0.57^{b}$ & $5.90 \pm 0.01^{\mathrm{d}}$ & $14.83 \pm 0.05^{\mathrm{c}}$ \\
\hline & 14 & $62.00 \pm 1.00^{\mathrm{b}}$ & $5.60 \pm 0.01^{\mathrm{f}}$ & $14.35 \pm 0.02^{\mathrm{d}}$ & $73.00 \pm 1.00^{\mathrm{b}}$ & $5.97 \pm 0.01^{\mathrm{d}}$ & $14.94 \pm 0.02^{\mathrm{bc}}$ \\
\hline \multirow[t]{3}{*}{$3 \mathrm{kGy}$} & 0 & $53.00 \pm 1.00^{\mathrm{ef}}$ & $5.09 \pm 0.07^{\mathrm{g}}$ & $14.00 \pm 0.10^{\mathrm{efg}}$ & $53.00 \pm 1.00^{c}$ & $5.09 \pm 0.07^{c}$ & $14.00 \pm 0.10^{c}$ \\
\hline & 7 & $52.00 \pm 1.00^{\mathrm{ef}}$ & $5.11 \pm 0.02^{\mathrm{g}}$ & $13.96 \pm 0.01^{\mathrm{fgh}}$ & $66.66 \pm 0.57^{\mathrm{c}}$ & $5.57 \pm 0.01^{\mathrm{c}}$ & $14.63 \pm 0.06^{\mathrm{cd}}$ \\
\hline & 14 & $54.33 \pm 0.57^{\mathrm{de}}$ & $5.08 \pm 0.02^{\mathrm{g}}$ & $13.98 \pm 0.07^{\text {efgh }}$ & $66.00 \pm 1.00^{\mathrm{c}}$ & $5.62 \pm 0.01^{\mathrm{c}}$ & $14.73 \pm 0.02^{\mathrm{cd}}$ \\
\hline \multirow[t]{3}{*}{$0 \mathrm{kGy}+2 \% \mathrm{MLF}$} & 0 & $57.66 \pm 0.57^{c}$ & $6.72 \pm 0.07^{\mathrm{e}}$ & $13.73 \pm 0.05^{\mathrm{h}}$ & $57.66 \pm 0.57^{\mathrm{d}}$ & $6.72 \pm 0.07^{\mathrm{e}}$ & $13.73 \pm 0.05^{\mathrm{ef}}$ \\
\hline & 7 & $56.66 \pm 0.57^{\mathrm{cd}}$ & $6.79 \pm 0.02^{\mathrm{de}}$ & $13.76 \pm 0.01^{\mathrm{gh}}$ & $61.33 \pm 0.57^{\mathrm{d}}$ & $6.85 \pm 0.01^{\mathrm{e}}$ & $13.99 \pm 0.05^{\mathrm{ef}}$ \\
\hline & 14 & $56.66 \pm 0.57^{\mathrm{cd}}$ & $6.71 \pm 0.03^{\mathrm{e}}$ & $13.79 \pm 0.01^{\mathrm{gh}}$ & $62.66 \pm 0.57^{\mathrm{de}}$ & $6.90 \pm 0.01^{\mathrm{e}}$ & $14.29 \pm 0.44^{\mathrm{de}}$ \\
\hline \multirow[t]{3}{*}{$1.5 \mathrm{kGy}+2 \% \mathrm{MLF}$} & 0 & $70.00 \pm 1.00^{\mathrm{a}}$ & $7.15 \pm 0.04^{b}$ & $15.13 \pm 0.20^{\mathrm{bc}}$ & $70.00 \pm 1.00^{\mathrm{a}}$ & $7.15 \pm 0.04^{\mathrm{a}}$ & $15.13 \pm 0.20^{\mathrm{a}}$ \\
\hline & 7 & $69.33 \pm 0.57^{\mathrm{a}}$ & $7.53 \pm 0.15^{\mathrm{a}}$ & $15.26 \pm 0.05^{\mathrm{ab}}$ & $77.66 \pm 0.57^{\mathrm{a}}$ & $7.43 \pm 0.01^{\mathrm{a}}$ & $15.44 \pm 0.05^{\mathrm{a}}$ \\
\hline & 14 & $68.00 \pm 1.00^{\mathrm{a}}$ & $7.12 \pm 0.01^{\mathrm{bc}}$ & $15.40 \pm 0.01^{\mathrm{a}}$ & $78.66 \pm 0.57^{\mathrm{a}}$ & $7.48 \pm 0.01^{\mathrm{a}}$ & $15.55 \pm 0.09^{\mathrm{a}}$ \\
\hline \multirow[t]{2}{*}{$3 \mathrm{kGy}+2 \% \mathrm{MLF}$} & 0 & $63.00 \pm 1.00^{\mathrm{b}}$ & $6.94 \pm 0.08^{\mathrm{d}}$ & $14.93 \pm 0.15^{\mathrm{c}}$ & $63.00 \pm 1.00^{\mathrm{b}}$ & $6.94 \pm 0.08^{b}$ & $14.93 \pm 0.15^{\mathrm{ab}}$ \\
\hline & 7 & $63.66 \pm 0.57^{b}$ & $6.89 \pm 0.01^{\mathrm{d}}$ & $14.88 \pm 0.03^{c}$ & $73.33 \pm 0.57^{b}$ & $7.22 \pm 0.01^{\mathrm{b}}$ & $15.31 \pm 0.05^{\mathrm{ab}}$ \\
\hline
\end{tabular}

This article is protected by copyright. All rights reserved 


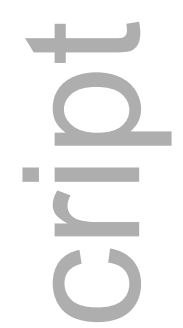

Table 3. Heme pigment in aerobic and vacuum packaged meat samples during storage

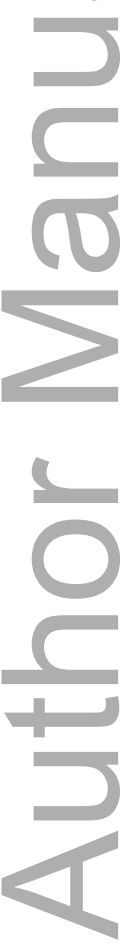

This article is protected by copyright. All rights reserved 
Results are means of triplicates $( \pm \mathrm{SD})$. Values with different letters in columns are significantly different (Tukey’s test, $\mathrm{p} \leq 0.05)$. MLF; Moringa Leaf Powder -

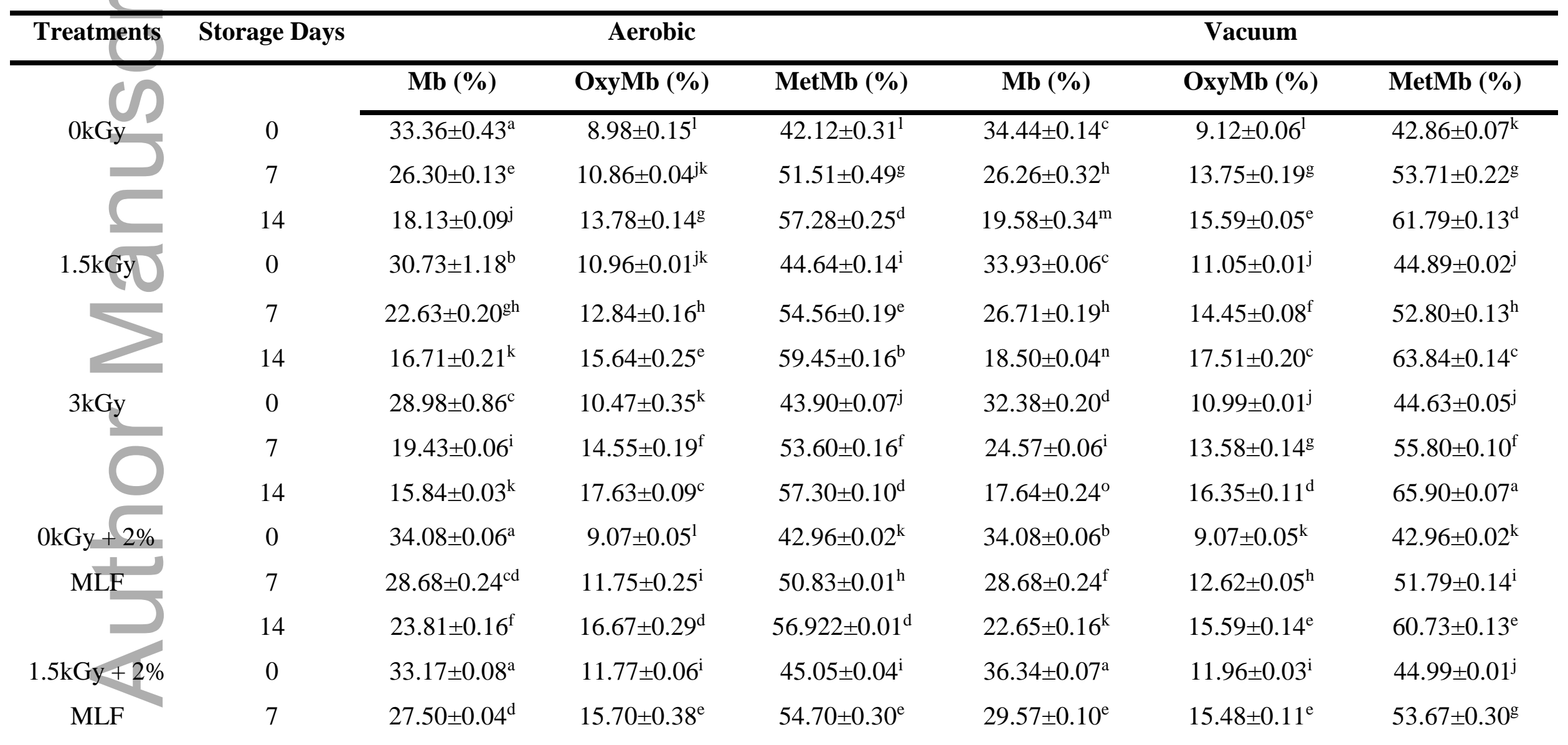

This article is protected by copyright. All rights reserved 


\begin{tabular}{cccccccc} 
& 14 & $21.52 \pm 0.19^{\mathrm{h}}$ & $18.58 \pm 0.13^{\mathrm{b}}$ & $61.62 \pm 0.31^{\mathrm{a}}$ & $23.54 \pm 0.26^{\mathrm{j}}$ & $18.50 \pm 0.14^{\mathrm{b}}$ & $64.63 \pm 0.31^{\mathrm{b}}$ \\
$3 \mathrm{kGy}+2 \%$ & 0 & $31.26 \pm 0.08^{\mathrm{b}}$ & $11.22 \pm 0.06^{\mathrm{ij}}$ & $44.97 \pm 0.01^{\mathrm{i}}$ & $35.65 \pm 0.03^{\mathrm{b}}$ & $11.72 \pm 0.03^{\mathrm{i}}$ & $44.79 \pm 0.03^{\mathrm{j}}$ \\
$\mathrm{MLF}$ & 7 & $22.72 \pm 0.22^{\mathrm{fg}}$ & $16.89 \pm 0.07^{\mathrm{d}}$ & $50.76 \pm 0.12^{\mathrm{h}}$ & $27.67 \pm 0.16^{\mathrm{g}}$ & $16.48 \pm 0.10^{\mathrm{d}}$ & $59.90 \pm 0.07^{\mathrm{f}}$ \\
& 14 & $15.71 \pm 0.13^{\mathrm{k}}$ & $19.48 \pm 0.07^{\mathrm{a}}$ & $58.74 \pm 0.33^{\mathrm{c}}$ & $20.59 \pm 0.15^{1}$ & $20.61 \pm 0.12^{\mathrm{a}}$ & $64.81 \pm 0.09^{\mathrm{b}}$ \\
\hline
\end{tabular}

This article is protected by copyright. All rights reserved 
Table 4. Mean values of microbial load in aerobic and vacuum packaged meat samples during storage

\begin{tabular}{|c|c|c|c|c|c|}
\hline \multirow{2}{*}{ Treatments } & \multirow[t]{2}{*}{ Storage Days } & \multicolumn{2}{|c|}{ Aerobic } & \multicolumn{2}{|c|}{ Vacuum } \\
\hline & & TAB (log CFU/g) & Coliform (log CFU/g) & TAB $(\log$ CFU/g) & Coliform (log CFU/g) \\
\hline & 0 & $7.03 \pm 0.01^{\mathrm{d}}$ & $5.23 \pm 0.02^{\mathrm{d}}$ & $7.03 \pm 0.01^{\mathrm{e}}$ & $5.23 \pm 0.02^{b}$ \\
\hline & 7 & $8.53 \pm 0.01^{\mathrm{b}}$ & $6.35 \pm 0.01^{\mathrm{b}}$ & $7.62 \pm 0.01^{\mathrm{b}}$ & $5.71 \pm 0,28^{\mathrm{a}}$ \\
\hline & 14 & $9.81 \pm 0.04^{\mathrm{a}}$ & $7.12 \pm 0.01^{\mathrm{a}}$ & $8.15 \pm 0.01^{\mathrm{a}}$ & $5.98 \pm 0.10^{\mathrm{a}}$ \\
\hline $1.5 \mathrm{kC}$ & 0 & $5.15 \pm 0.02^{\mathrm{h}}$ & ND & $5.15 \pm 0.02^{\mathrm{j}}$ & ND \\
\hline & 7 & $5.36 \pm 0.02^{\mathrm{g}}$ & ND & $5.68 \pm 0.01^{\mathrm{h}}$ & ND \\
\hline & 14 & $5.98 \pm 0.02^{\mathrm{f}}$ & ND & $5.98 \pm 0.01^{\mathrm{g}}$ & ND \\
\hline & 0 & $4.23 \pm 0.02^{\mathrm{m}}$ & ND & $4.23 \pm 0.02^{\mathrm{n}}$ & ND \\
\hline & 7 & $4.52 \pm 0.01^{1}$ & ND & $4.65 \pm 0.01^{1}$ & ND \\
\hline & 14 & $4.67 \pm 0.01^{\mathrm{k}}$ & ND & $4.77 \pm 0.02^{\mathrm{k}}$ & ND \\
\hline $0 \mathrm{kGy}+$ & 0 & $6.74 \pm 0.02^{\mathrm{e}}$ & $4.86 \pm 0.04^{\mathrm{f}}$ & $6.74 \pm 0.02^{\mathrm{f}}$ & $4.86 \pm 0.04^{\mathrm{c}}$ \\
\hline & 7 & $7.02 \pm 0.01^{\mathrm{d}}$ & $5.17 \pm 0.01^{\mathrm{e}}$ & $7.03 \pm 0.01^{\mathrm{d}}$ & $4.90 \pm 0.01^{b}$ \\
\hline & 14 & $7.24 \pm 0.02^{\mathrm{c}}$ & $5.35 \pm 0.01^{\mathrm{c}}$ & $7.31 \pm 0.09^{c}$ & $4.97 \pm 0.01^{\mathrm{b}}$ \\
\hline $1.5 \mathrm{kGy}+2$ & 0 & $5.04 \pm 0.01^{\mathrm{i}}$ & ND & $5.04 \pm 0.01^{\mathrm{k}}$ & ND \\
\hline & 7 & $5.12 \pm 0.01^{\mathrm{h}}$ & ND & $5.03 \pm 0.01^{\mathrm{j}}$ & ND \\
\hline & 14 & $5.38 \pm 0.01^{\mathrm{g}}$ & ND & $5.20 \pm 0.01^{\mathrm{i}}$ & ND \\
\hline $3 \mathrm{kGy}+2 \% \mathrm{MLF}$ & 0 & $4.17 \pm 0.02^{\mathrm{n}}$ & ND & $4.17 \pm 0.02^{\circ}$ & ND \\
\hline
\end{tabular}

This article is protected by copyright. All rights reserved 
Table 5. Sensory scores of meatballs stored in aerobic packaging

\begin{tabular}{|c|c|c|c|c|c|c|}
\hline Treatments & Storage Days & Appearance & Flavor & Texture & Taste & $\mathbf{O A}$ \\
\hline \multirow[t]{3}{*}{ 0kGy } & 0 & $8.25 \pm 0.70^{\mathrm{a}}$ & $7.5 \pm 1.35^{\mathrm{a}}$ & $7.1 \pm 0.77^{\mathrm{ab}}$ & $7.3 \pm 1.03^{\mathrm{a}}$ & $7.5 \pm 0.81^{\mathrm{ab}}$ \\
\hline & 7 & $7.15 \pm 1.30^{\mathrm{b}}$ & $6.7 \pm 1.03^{\mathrm{b}}$ & $6.8 \pm 0.95^{\mathrm{b}}$ & $6.9 \pm 1.16^{b}$ & $6.8 \pm 0.97^{b}$ \\
\hline & 14 & $6.1 \pm 1.43^{c}$ & $6.2 \pm 0.91^{\mathrm{c}}$ & $5.7 \pm 1.20^{c}$ & $6.1 \pm 1.42^{c}$ & $6.3 \pm 1.10^{c}$ \\
\hline \multirow[t]{3}{*}{$1.5 \mathrm{kGy}$} & 0 & $7.86 \pm 0.71^{\mathrm{ab}}$ & $7.2 \pm 1.30^{\mathrm{b}}$ & $6.9 \pm 0.80^{\mathrm{b}}$ & $7.2 \pm 0.90^{\mathrm{a}}$ & $7.2 \pm 0.67^{c}$ \\
\hline & 7 & $7.1 \pm 0.71^{b}$ & $6.5 \pm 1.10^{b}$ & $6.2 \pm 0.90^{\mathrm{b}}$ & $6.5 \pm 1.20^{\mathrm{b}}$ & $6.4 \pm 0.82^{b}$ \\
\hline & 14 & $6.8 \pm 0.74^{c}$ & $5.9 \pm .080^{c}$ & $5.8 \pm 1.40^{c}$ & $6.3 \pm 1.25^{\mathrm{c}}$ & $6.1 \pm 1.02^{c}$ \\
\hline \multirow{3}{*}{$3 \mathrm{kGy}$} & 0 & $7.5 \pm 0.53^{\mathrm{ab}}$ & $7.3 \pm 1.15^{\mathrm{a}}$ & $7.0 \pm 0.90^{\mathrm{a}}$ & $7.1 \pm 1.01^{\mathrm{a}}$ & $7.3 \pm 0.77^{\mathrm{ab}}$ \\
\hline & 7 & $7.2 \pm 1.30^{\mathrm{b}}$ & $6.8 \pm 0.95^{\mathrm{b}}$ & $6.7 \pm 1.52^{\mathrm{b}}$ & $6.9 \pm 1.19^{\mathrm{b}}$ & $6.9 \pm 0.77^{\mathrm{b}}$ \\
\hline & 14 & $6.5 \pm 1.52^{c}$ & $6.5 \pm 0.90^{c}$ & $6.1 \pm 1.20^{c}$ & $6.5 \pm 1.04^{c}$ & $6.4 \pm 1.03^{c}$ \\
\hline \multirow{3}{*}{$0 \mathrm{kGy}+2 \% \mathrm{MLF}$} & 0 & $8 \pm 0.65^{a}$ & $7.4 \pm 1.32^{\mathrm{a}}$ & $7.0 \pm 1.10^{\mathrm{ab}}$ & $7.2 \pm 0.98^{\mathrm{a}}$ & $7.4 \pm 0.74^{\mathrm{a}}$ \\
\hline & 7 & $7.5 \pm 0.70^{\mathrm{b}}$ & $6.9 \pm 1.14^{\mathrm{b}}$ & $6.7 \pm 0.99^{b}$ & $6.7 \pm 1.06^{\mathrm{b}}$ & $6.9 \pm 0.77^{b}$ \\
\hline & 14 & $7.1 \pm 1.20^{\mathrm{c}}$ & $6.4 \pm 1.01^{\mathrm{c}}$ & $6.2 \pm 1.30^{c}$ & $6.4 \pm 1.10^{c}$ & $6.5 \pm 1.32^{c}$ \\
\hline \multirow{2}{*}{$1.5 \mathrm{kGy}+2 \% \mathrm{MLF}$} & 0 & $7.8 \pm 0.77^{\mathrm{ab}}$ & $7.3 \pm 1.16^{\mathrm{ab}}$ & $7.0 \pm 0.87^{\mathrm{a}}$ & $7.3 \pm 1.15^{\mathrm{a}}$ & $7.4 \pm 0.93^{\mathrm{abc}}$ \\
\hline & 7 & $7.2 \pm 0.82^{b}$ & $6.6 \pm 0.70^{b}$ & $6.7 \pm 1.03^{b}$ & $6.4 \pm 1.07^{b}$ & $6.7 \pm 0.85^{b}$ \\
\hline
\end{tabular}




\begin{tabular}{|c|c|c|c|c|c|c|}
\hline & 14 & $6.9 \pm 0.90^{c}$ & $6.4 \pm 0.74^{c}$ & $6.3 \pm 0.93^{c}$ & $6.3 \pm 1.03^{c}$ & $6.4 \pm 1.05^{\mathrm{c}}$ \\
\hline $3 \mathrm{kGy}+2 \% \mathrm{MLF}$ & 0 & $7.6 \pm 0.80^{\mathrm{b}}$ & $7.4 \pm 1.43^{\mathrm{ab}}$ & $7.0 \pm 0.90^{\mathrm{ab}}$ & $7.1 \pm 0.88^{a}$ & $7.3 \pm 1.01^{\mathrm{bc}}$ \\
\hline & 7 & $6.8 \pm 1.30^{\mathrm{b}}$ & $6.5 \pm 1.33^{\mathrm{b}}$ & $6.6 \pm 0.90^{\mathrm{b}}$ & $6.2 \pm 0.98^{b}$ & $6.5 \pm 0.98^{b}$ \\
\hline 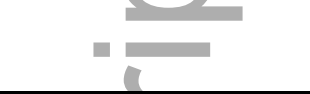 & 14 & $6.76 \pm 1.42^{\mathrm{c}}$ & $6.3 \pm 1.21^{\mathrm{c}}$ & $6 \pm 1.10^{c}$ & $6.2 \pm 1.07^{\mathrm{c}}$ & $6.1 \pm 1.10^{c}$ \\
\hline
\end{tabular}

The values are mean \pm SD of ten independent determinations. The means carrying different letters in a column differed significantly. OA: Overall

Acceptability; MLF: Moringa Leaf Powder

Table 6. Sensory scores of meatballs stored in vacuum packaging

\begin{tabular}{|c|c|c|c|c|c|c|}
\hline Treatments & Storage Days & Appearance & Flavor & Texture & Taste & $\mathbf{O A}$ \\
\hline \multirow{3}{*}{ 0kGy } & 0 & $8.25 \pm 0.70^{\mathrm{ab}}$ & $7.5 \pm 1.35^{\mathrm{b}}$ & $7.1 \pm 0.77^{\mathrm{ab}}$ & $7.3 \pm 1.03^{\mathrm{a}}$ & $7.5 \pm 0.81^{\mathrm{a}}$ \\
\hline & 7 & $7.3 \pm 0.72^{b}$ & $6.4 \pm 1.21^{\mathrm{b}}$ & $6.9 \pm 1.18^{\mathrm{b}}$ & $6.8 \pm 1.16^{\mathrm{b}}$ & $6.8 \pm 0.88^{b}$ \\
\hline & 14 & $6.4 \pm 0.80^{c}$ & $6.1 \pm 0.90^{c}$ & $6.0 \pm 1.36^{\mathrm{c}}$ & $6.0 \pm 0.90^{c}$ & $6.2 \pm 0.90^{c}$ \\
\hline \multirow[t]{3}{*}{$1.5 \mathrm{kGy}$} & 0 & $7.86 \pm 0.71^{\mathrm{d}}$ & $7.2 \pm 1.30^{\mathrm{ab}}$ & $6.9 \pm 0.80^{\mathrm{ab}}$ & $7.2 \pm 0.90^{\mathrm{a}}$ & $7.2 \pm 0.67^{\mathrm{a}}$ \\
\hline & 7 & $6.9 \pm 0.71^{\mathrm{b}}$ & $6.7 \pm 1.21^{\mathrm{b}}$ & $6.8 \pm 1.10^{\mathrm{b}}$ & $6.4 \pm 1.13^{\mathrm{b}}$ & $6.7 \pm 0.80^{\mathrm{b}}$ \\
\hline & 14 & $6.8 \pm 0.82^{c}$ & $6.4 \pm 1.02^{\mathrm{c}}$ & $6.3 \pm 1.32^{\mathrm{c}}$ & $6.2 \pm 1.43^{\mathrm{c}}$ & $6.3 \pm 0.77^{c}$ \\
\hline \multirow{3}{*}{$3 k G y$} & 0 & $7.5 \pm 0.53^{b}$ & $7.3 \pm 1.15^{\mathrm{b}}$ & $7.0 \pm 0.90^{\mathrm{a}}$ & $7.1 \pm 1.01^{\mathrm{a}}$ & $7.3 \pm 0.77^{\mathrm{a}}$ \\
\hline & 7 & $7.3 \pm 0.77^{\mathrm{b}}$ & $6.2 \pm 1.22^{\mathrm{b}}$ & $6.9 \pm 0.98^{b}$ & $6.8 \pm 1.07^{\mathrm{b}}$ & $6.8 \pm 0.84^{b}$ \\
\hline & 14 & $6.8 \pm 0.85^{c}$ & $6.3 \pm 1.10^{c}$ & $6.2 \pm 1.08^{c}$ & $6.4 \pm 1.41^{\mathrm{c}}$ & $6.3 \pm 0.77^{c}$ \\
\hline \multirow{2}{*}{$0 \mathrm{kGy}+2 \% \mathrm{MLF}$} & 0 & $8 \pm 0.65^{\mathrm{a}}$ & $7.4 \pm 1.32^{\mathrm{a}}$ & $7.0 \pm 1.10^{\mathrm{b}}$ & $7.2 \pm 0.98^{\mathrm{a}}$ & $7.4 \pm 0.74^{\mathrm{a}}$ \\
\hline & 7 & $7.5 \pm 0.99^{b}$ & $6.9 \pm 0.94^{b}$ & $6.5 \pm 0.90^{\mathrm{b}}$ & $6.6 \pm 1.33^{b}$ & $6.8 \pm 0.91^{b}$ \\
\hline
\end{tabular}

This article is protected by copyright. All rights reserved 


\begin{tabular}{|c|c|c|c|c|c|c|}
\hline & 14 & $7 \pm 1.01^{\mathrm{c}}$ & $6.4 \pm 0.74^{c}$ & $6.1 \pm 1.41^{\mathrm{c}}$ & $6.3 \pm 1.21^{\mathrm{c}}$ & $6.1 \pm 1.01^{\mathrm{c}}$ \\
\hline $1.5 \mathrm{kGy}+2 \% \mathrm{MLF}$ & 0 & $7.8 \pm 0.77^{\mathrm{bc}}$ & $7.3 \pm 1.16^{\mathrm{a}}$ & $6.9 \pm 0.87^{\mathrm{ab}}$ & $7.2 \pm 1.15^{\mathrm{a}}$ & $7.4 \pm 0.93^{\mathrm{a}}$ \\
\hline \multirow{5}{*}{$3 \mathrm{kGy}+2 \% \mathrm{MLF}$} & 7 & $7.2 \pm 1.10^{b}$ & $6.9 \pm 1.30^{\mathrm{b}}$ & $6.8 \pm 1.17^{b}$ & $6.3 \pm 1.10^{\mathrm{b}}$ & $6.8 \pm 0.85^{\mathrm{b}}$ \\
\hline & 14 & $6.7 \pm 0.77^{\mathrm{c}}$ & $6.4 \pm 1.04^{\mathrm{c}}$ & $6.4 \pm 1.10^{c}$ & $6.2 \pm 1.15^{\mathrm{c}}$ & $6.3 \pm 0.74^{c}$ \\
\hline & 0 & $7.6 \pm 0.80^{\mathrm{cd}}$ & $7.4 \pm 1.43^{b}$ & $6.8 \pm 0.90^{\mathrm{ab}}$ & $7.1 \pm 0.88^{a}$ & $7.3 \pm 1.01^{\mathrm{a}}$ \\
\hline & 7 & $7.1 \pm 0.71^{b}$ & $6.3 \pm 1.25^{\mathrm{b}}$ & $6.7 \pm 1.18^{\mathrm{b}}$ & $6.3 \pm 1.23^{\mathrm{b}}$ & $6.6 \pm 0.84^{b}$ \\
\hline & 14 & $6.6 \pm 0.74^{\mathrm{c}}$ & $6.2 \pm 1.17^{\mathrm{c}}$ & $6.1 \pm 1.30^{c}$ & $6.1 \pm 1.20^{c}$ & $6.2 \pm 0.91^{\mathrm{c}}$ \\
\hline
\end{tabular}

The values are mean \pm SD of ten independent determinations. The means carrying different letters in a column differed significantly. OA: Overall Acceptability; MLF: Moringa Leaf Powder

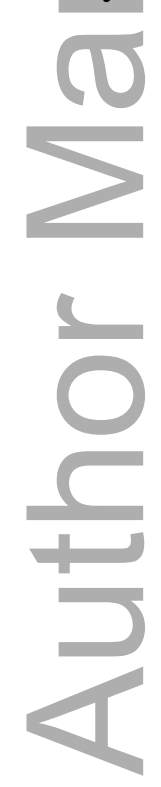

This article is protected by copyright. All rights reserved 


\section{University Library}

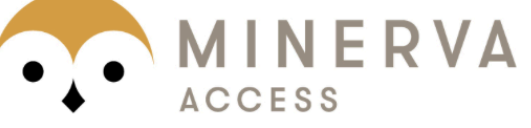

A gateway to Melbourne's research publications

Minerva Access is the Institutional Repository of The University of Melbourne

Author/s:

Nisar, MF;Arshad, MS;Yasin, M;Khan, MK;Afzaal, M;Sattar, S;Suleria, HAR

Title:

Evaluation of gamma irradiation and moringa leaf powder on quality characteristics of meat balls under different packaging materials

Date:

2020-07-28

\section{Citation:}

Nisar, M. F., Arshad, M. S., Yasin, M., Khan, M. K., Afzaal, M., Sattar, S. \& Suleria, H. A. R. (2020). Evaluation of gamma irradiation and moringa leaf powder on quality characteristics of meat balls under different packaging materials. JOURNAL OF FOOD PROCESSING AND PRESERVATION, 44 (10), https://doi.org/10.1111/jfpp.14748.

Persistent Link:

http://hdl.handle.net/11343/268088 